\title{
Analysis of methane hazard in longwall working equipped with a powered longwall complex
}

\author{
Leszek Sobik ${ }^{1}$, Jarostaw Brodny ${ }^{2, *}$, Gennady Buyalich ${ }^{3}$, and Pavel Strelnikov ${ }^{3}$ \\ ${ }^{1}$ Polska Grupa Górnicza S.A., KWK ROW ruch Chwałowice, ul. Przewozowa 4, 44-206 Rybnik, \\ Poland \\ ${ }^{2}$ Silesian University of Technology, Faculty of Organization and Management, Roosevelta 26, \\ 41-800 Zabrze, Poland \\ ${ }^{3}$ Kuzbass State Technical University, Mezhdurechensk branch, 652881, Stroitelei Avenue, 36, \\ Mezhdurechensk, Russia
}

\begin{abstract}
Most of currently exploited hard coal seams has a very high degree of methane saturation. Consequently, the mining process of such deposits generates substantial amounts of methane. This in turn increases the risk of fire and/or explosion of this gas. Methane hazard is currently one of the most dangerous threats occurring in the process of underground mining exploitation. In particular, this applies to longwall excavations where the rock mass mining process generates the highest level of this gas. Commonly used high-performance longwall complexes cause an increase in the amount of coal output, which also causes an increase in the amount of methane released. In order to prevent hazardous concentrations, appropriate ventilation systems and atmosphere monitoring in mining excavations are used. The paper discusses currently used methods designed to limit risks caused by methane such as methane drainage. The paper presents an example of the use of an innovative method of analysing methane risk status and measures aimed at minimizing it. The developed method is based on air parameters in the actual mining area which were then used to create a method of ventilation for such excavations. The method combines advanced model analysis and experience of mine employees and integrates academic and practical knowledge. The main objective of the activities presented in the article was to improve the safety of mining operation
\end{abstract}

\section{Introduction}

Currently, the most popular method of underground exploitation of hard coal is a longwall system. It is a popular high-performance system for mining of rockmass. Its main components are a mining machine, horizontal transport equipment and a powered roof support. The continuity and efficiency as well as safety of the mining process are mainly determined by the roof support. In general, it can be stated that the roof support has a fundamental impact on the safety in terms of unground mining process. This applies to both gallery support [1] and longwall support [16].

\footnotetext{
* Corresponding author: jaroslaw.brodny@polsl.pl
} 
A powered roof support is currently the most popular machine used in longwall mining. The powered roof support is designed to protect headings against the impact of the rock mass and allows to move the remaining machines of the longwall complex such as shearers or plow systems, mining machines, conveyors or crushers. The roof support comprises individual sections cooperating with each other. The protective roof support stays in contact with the gallery support in places where a longwall excavation intersects with a gallery. The area protected by the roof support, called a longwall excavation, is used also during the ventilation process [13]. Proper ventilation of an underground area is crucial for mining operation [10]. This particularly applies to the longwall excavation, where the basic mining process is conducted. Therefore, it can be assumed that the longwall excavation together with gallery excavations are a ventilation duct supplying the area with fresh air. The fresh air enters from one side, flows into the longwall area and flows out through the other side. Circulation of air in a longwall excavation is presented in Figure 1.

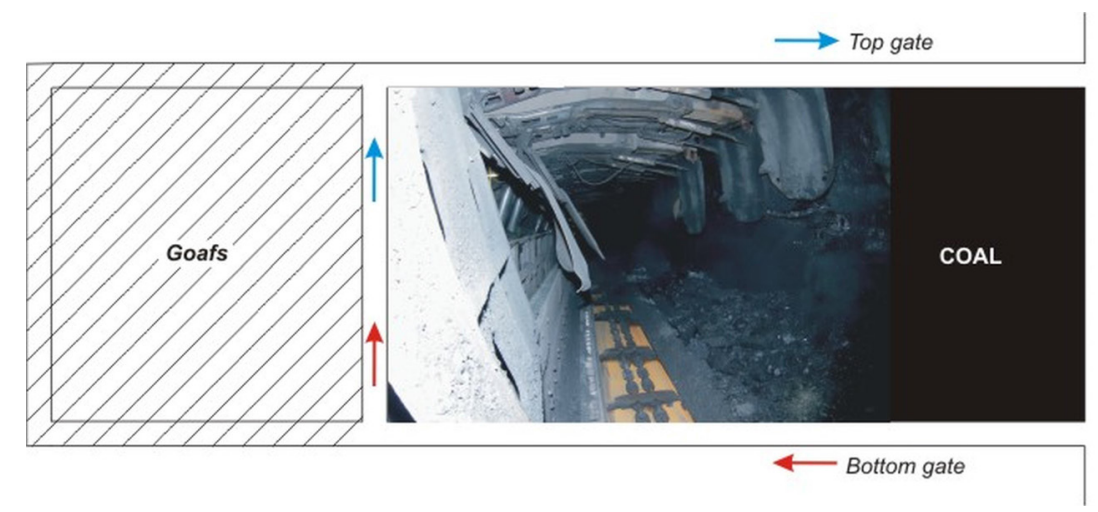

Fig. 1. Scheme of air circulation in a longwall excavation.

Apart from supplying the workers in the longwall excavation with fresh air, the ventilation system must prevent dangerous concentrations of methane. This gas is one of the biggest threats in the unground mining industry. It occurs in coal deposits and is released during mining. Methane is flammable and combustible when mixed with oxygen at certain concentrations. As a result, the dimensions of the excavation and the ventilation system must be designed to prevent such high levels of this gas [4, 8].

Underground coal deposits have various levels of saturation with methane, from nonmethane coal deposits to deposits with very high levels of methane saturation. Unfortunately, the level of saturation of currently exploited deposits increases simultaneously increasing the methane hazard. Deeper mining activity intensifies the possibility of others hazard including fire [2, 3] and climatic hazard as well as contributes to increased number of tremors. Seams deposited at greater depths are linked to associated hazards (fire, tremors, temperature and methane hazard combined) [7, 9]. All these factors contribute to the complexity of the mining process. Consequently, the selection of a proper ventilation system and roof support is challenging.

Among natural hazards, the most important from the point of view of ventilation safety are methane and fire hazards $[11,14,15,18]$. The effects of fires and methane explosion are particularly dangerous. Methane hazard increases with the depth of mining activity and intensity of mining. Seventy-four methane fires occurred in Polish hard coal mines, with thirteen fatalities between 2007 and 2016 and also several methane explosions that led to twenty-eight fatalities [6]. The Polish mining industry extracted 44.44 million tonnes of coal from methane seams in 2018, while non-metallic seams produced 13.94 million tonnes of coal. 
It should be noted that methane is also a very valuable energy gas, which can be successfully used as a clean energy resource. The extraction of methane from coal has become a part of activities conducted by a mine with demethylation and methane capture gaining in popularity. The mine with the highest methane content in Poland in 2018 was KWK Budryk, with 155.23 million $\mathrm{m}^{3}$ of $\mathrm{CH}_{4}$ in a year, which is 13 million $\mathrm{m}^{3}$ more compared to 2017 [6].

Nevertheless, methane poses a serious threat to this process in its essential operation. Thus, it becomes crucial to select an appropriate ventilation system and equipment for the excavations so as to prevent critical concentrations of this gas $[5,12,17]$.

The article presents an example of a change in the longwall ventilation system during mining, which is quite unusual when it comes to mining. Complex and dangerous conditions that prevailed in this longwall when ventilating it with the U-type system made it necessary to either make changes or stop operation. In this case, it was decided to change the ventilation system from U- to Y-type. This decision made it possible to safely complete the operation, without major issues or dangerous events. Undoubtedly, this operation resulted in an improvement in safety in the longwall and showed new possible outcomes of modifying ventilation systems. The experience gained during the process will be used in other mines of Polska Grupa Górnicza S.A. as the company strives to improve the safety of the mining process.

\section{Selecting a proper longwall ventilation system}

The purpose of the longwall excavation ventilation system is to supply air to a longwall in such a way as to prevent dangerous concentrations of methane and other gases. The effectiveness of dilution and quick methane removal from these excavations is largely determined by the selection of an optimal ventilation method. longwalls are ventilated using various methods also those including galleries [8, 12].

In Polish hard coal mines, a ventilation system is commonly based on the U-system, starting from the border and running to the mining site. This system is used for ventilation of high-performance longwalls, in case of high methane risk. It is also common, although to a lesser extent, to use Y-type systems in different varieties. The Y-type ventilation system is used in both methane and non-methane longwalls, with or without fire hazard. In the conditions of Polish mines, the Z- and H-type ventilation system is also used. The Z-type system requires minimal preparatory works before starting the operation, while the H-type system is used in case of high methane hazard.

Each of them has advantages and disadvantages. Prior to deciding which system is appropriate for certain conditions, a number of technical organisational requirements must be met. Moreover, the system must be economically viable. Diagrams of currently used ventilation systems in Polish hard coal mines are shown in Figure 2. 
a)

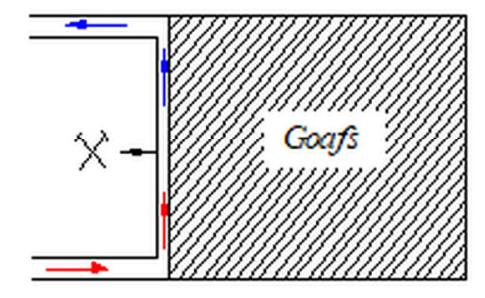

c)

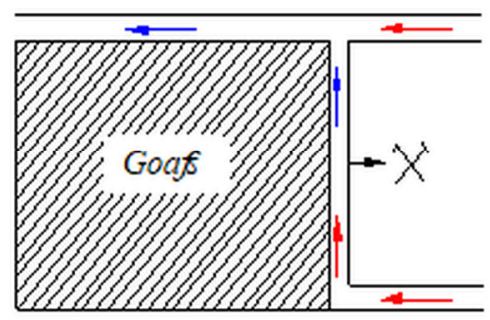

b)

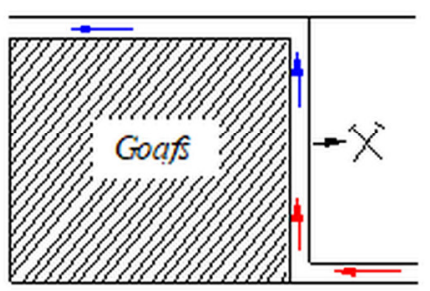

d)

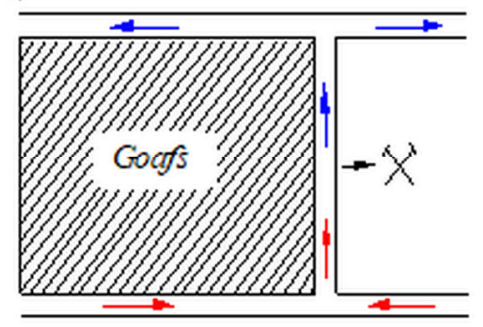

Fig. 2. Currently used ventilation systems in hard coal mines, U-type (a), Z-type (b), Y-type (c) and H-type system (d).

\section{Research on the optimal ventilation method}

The article discusses a ventilation system in one of the actual longwalls exploited in an underground hard coal mine as an example of adapting the ventilation system to mining and geological conditions and increasing methane hazard. The longwall (S/z III-III, seam 408/1) was based on a longwall system with full cave-in of floor rocks from March 2018 to May 2019. It was $240 \mathrm{~m}$ long, the panel was $870 \mathrm{~m}$ long, mining thickness was $1.8 \mathrm{~m}$ and the operating depth was between 645 and $780 \mathrm{~m}$. The seam 408/1 in the IIIz area was classified in the third category of methane hazard. The excavations of the S/III longwall area from the seam 408/1 together with the air discharge routes to the exhaust shaft are covered by the boundaries of the category III methane field, water hazard level I and class B coal dust explosion hazard.

This seam is free of methane and rock related hazards and with no cases of registered rock bursts. On the basis of the research on coal spontaneous combustion indexes carried out by the Central Mining Institute in Katowice, the seam 408/1 located in the area of the longwall covered by the analysis was qualified to group IV of spontaneous combustion indexes with high coal propensity to spontaneous combustion. The calculated spontaneous combustion index was $\mathrm{Sza}=116^{\circ} \mathrm{C} / \mathrm{min}$ and the activation energy Ao $=47.9 \mathrm{~kJ} / \mathrm{mol}$. The designated incubation period of fire determined on the basis of laboratory tests, without taking into account fire prevention, was forty-seven days. The amount of air supplied to the longwall was $1000 \mathrm{~m}^{3} / \mathrm{min}$, and $2100 \mathrm{~m}^{3} / \mathrm{min}$ to the longwall area. The predicted absolute methane content of the longwall for the extraction of $2400 \mathrm{t} / \mathrm{d}$ was $35.36 \mathrm{~m}^{3} \mathrm{CH}_{4} / \mathrm{min}$. The absolute methane content was $54.18 \mathrm{~m}^{3} \mathrm{CH}_{4} / \mathrm{min}$, the ventilation methane content was 21.19 $\mathrm{m}^{3} \mathrm{CH}_{4} / \mathrm{min}$, and the amount of methane captured by demethanation was $32.99 \mathrm{~m}^{3} \mathrm{CH}_{4} / \mathrm{min}$. The efficiency of demethanation was therefore about $60.8 \%$.

There were numerous cases when methane concentration exceeded allowable values during the mining process. This resulted in power outages, which in turn resulted in interruptions in operation. This made it much more difficult to run the operation, disturbing the efficiency of the process and leading to the danger of explosion or methane fire. 
The list of ventilation parameters for this longwall (ventilated by the U-type system) together with the number of registered cases when permissible methane concentrations were exceeded, is presented in Table 1.

Table 1. Results of measurements for a longwall with U-type ventilation system.

\begin{tabular}{|c|c|c|c|}
\hline Month & $\begin{array}{c}\text { Air volume } \\
{\left[\mathbf{m}^{3} / \mathbf{m i n}\right] /\left[\mathbf{m}^{3} / \mathbf{s}\right]}\end{array}$ & $\begin{array}{c}\text { Absolute methane content } \\
\text { (average/month) }\left[\mathrm{m}^{3} \mathrm{CH}_{4} / \mathrm{min}\right]\end{array}$ & $\begin{array}{c}\mathrm{CH}_{4} \% \text { limit } \\
\text { value exceeded }\end{array}$ \\
\hline VI & $\begin{array}{c}990 / 16.50 \\
1377 / 22.95\end{array}$ & $\begin{array}{l}\text { Vent. } 17.71 \\
\text { Demet. } 23.72 \\
\text { Total } 41.43\end{array}$ & 54 \\
\hline VII & $\begin{array}{l}954 / 15.90 \\
1395 / 23.25\end{array}$ & \multirow{2}{*}{$\begin{array}{l}\text { Vent. } 15.23 \\
\text { Demet. } 23.95 \\
\text { Total } 39.18\end{array}$} & \multirow[b]{2}{*}{290} \\
\hline VII & $\begin{array}{c}968 / 16.14 \\
1458 / 24.30\end{array}$ & & \\
\hline VIII & $\begin{array}{l}986 / 16.44 \\
1422 / 23.70\end{array}$ & \multirow{2}{*}{$\begin{array}{l}\text { Vent. } 16.41 \\
\text { Demet. } 28.09 \\
\text { Total } 44.50\end{array}$} & \multirow[b]{2}{*}{159} \\
\hline VIII & $\begin{array}{c}998 / 16.64 \\
1278 / 21.30\end{array}$ & & \\
\hline
\end{tabular}

The conditions of this area were improved by changing the ventilation system to a $\mathrm{Y}$ type system.

This decision was followed by number of other changes. It was agreed that further operation based on the U-type system may result in discontinuation of the mining process.

After applying the Y-type ventilation system, the measurements were repeated, and much more favourable results were observed in terms of critical concentrations of methane. The results are presented in Table 2.

Table 2. Results of measurements for a longwall with a Y-type ventilation.

\begin{tabular}{|c|c|c|c|}
\hline Month & $\begin{array}{c}\text { Air volume } \\
{\left[\mathrm{m}^{3} / \mathbf{m i n}\right] /\left[\mathbf{m}^{3} / \mathbf{s}\right]}\end{array}$ & $\begin{array}{l}\text { Absolute methane content } \\
\text { (average/month) } \\
{\left[\mathrm{m}^{3} \mathbf{C} \mathrm{H}_{4} / \mathrm{min}\right]}\end{array}$ & $\begin{array}{c}\mathrm{CH}_{4} \% \text { limit } \\
\text { value } \\
\text { exceeded }\end{array}$ \\
\hline IX & $\begin{array}{l}1000 / 16.66 \\
1583 / 26.39\end{array}$ & $\begin{array}{l}\text { Vent. } 15.08 \\
\text { Demet. } 29.15 \\
\text { Total } 44.23\end{array}$ & 3 \\
\hline$X$ & $\begin{array}{c}1037 / 17.29 \\
549 / 9.15 \\
1696 / 28.27\end{array}$ & $\begin{array}{c}\text { Vent. } 21.19 \\
\text { Demet. } 32.99 \\
\text { Total } 54.18\end{array}$ & 4 \\
\hline XI & $\begin{array}{c}1033 / 17.22 \\
585 / 9.75 \\
1705 / 28.42 \\
\end{array}$ & $\begin{array}{l}\text { Vent. } 21.89 \\
\text { Demet. } 30.64 \\
\text { Total } 52.53 \\
\end{array}$ & 2 \\
\hline XII & $\begin{array}{c}1040 / 17.34 \\
567 / 9.45 \\
1601 / 26.68\end{array}$ & $\begin{array}{l}\text { Vent. } 21.60 \\
\text { Demet. } 25.69 \\
\text { Total } 38.29\end{array}$ & - \\
\hline
\end{tabular}

The research team measured changes in methane concentration in pivotal areas twiceprior to and after the ventilation system was changed. 


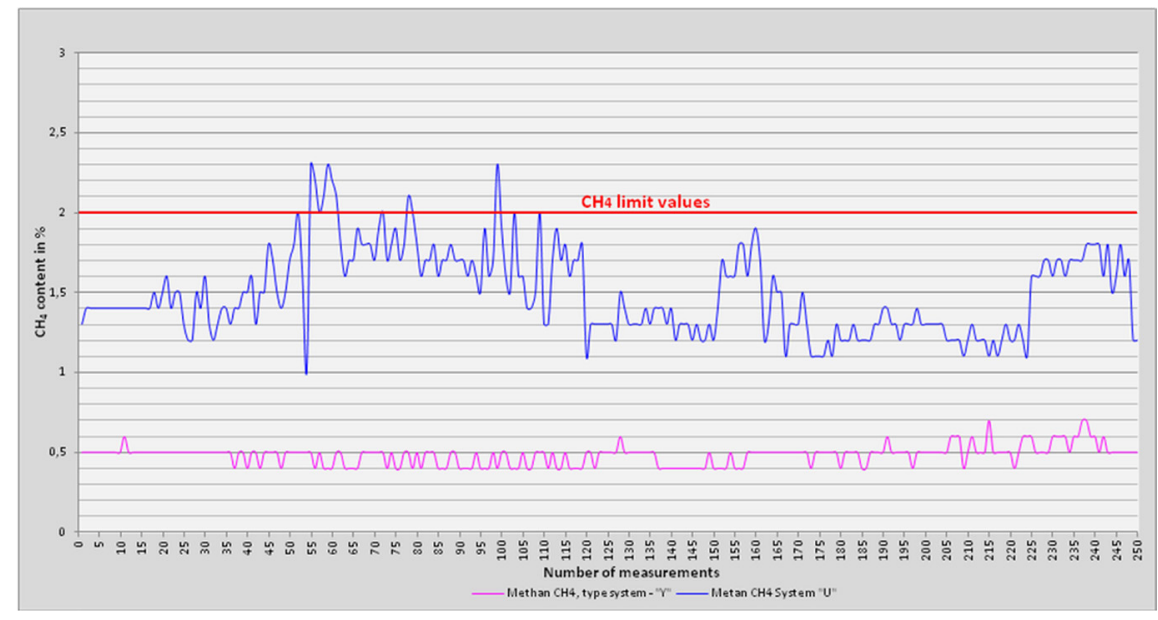

Fig. 3. Methane concentration; with U- and Y-type ventilation system.

The analysis of the results indicates that the change from the U-type ventilation system to Y-type has resulted in a significant improvement of working conditions. The methane concentration and the number of stoppages caused by these exceedances have decreased.

\section{Conclusion}

The example presented in the paper clearly indicates that adequate ventilation system is crucial for the safety and efficiency of the mining exploitation process. The amount of methane emitted during the initial operation of the longwall based on the U-type ventilation system was only slightly dependent on the actual daily output. Due to the fact that the permissible methane content at the longwall outlet is exceeded during mining operation, it was decided to change the type of a ventilation system. The initial U-type ventilation system with one-sided air supply and discharge along the body of coal was replaced with the Y-type ventilation system. As expected, the changed increased the efficiency of demethanation and caused the removal of the zone of high concentrations of methane from the immediate vicinity of the longwall. This has significantly reduced the number of times when $\mathrm{CH}_{4}$ concentrations were exceeded, as shown in Table 2. Proper analysis and selection should be conducted in the initial phase of planning. The conditions of the mining area presented in the paper allowed to conduct analysis and selection after the longwall had been developed which improved the safety of the whole mining process.

\section{References}

1. J. Brodny, Arch. Min. Sci. 56:2, 303-318 (2011)

2. J. Brodny, M. Tutak, 16th Intern. Multidisci. Scie. SGEM Conf. Proce., 1:2, 299-306 (2016)

3. J. Brodny, M. Tutak, J. of Appli. Fld. Mech. 11:3, 545-553 (2018)

4. J. Brodny, M. Tutak, Publ. on HRČ. Tehn. Vjes. - Tech. Gaze. 25:1, 271-276 (2018)

5. D. Felka, J. Brodny, Pol. Spri. Intern. Publi. AG, Intel. Syst. in Prod. Engine. and Mainte. ISPEM, Adva. in Intel. Syst. and Comp. 637, 151-160 (2017)

6. Raport 2018. Górnictwo Wegla Kamiennego w Polsce (GWKP, Kraków, 2019)

7. M. Tutak, J. Brodny, IOP Conf. Series: Earth Envir. Sci., 95, 042025 (2017) 
8. M. Tutak, J. Brodny, Energies, 11:11, 3076 (2018)

9. M. Tutak, J. Brodny, Int. J. Environ. Res. Public Health, 16, 1406 (2019)

10. M. Tutak, J. Brodny, Energies, 12, 3840 (2019)

11. M. Tutak, J. Brodny, E3S Web Conf., 29 (2018)

12. M. Tutak, J. Brodny, SGEM, 17:13, 437-444 (2017)

13. D. Szurgacz, L. Sobik, J. Brodny, Geolinks Intern.Conf. Geosci. Conf. Proce. Book, 1:1, 201-209 (2019)

14. D. Szurgacz, L. Sobik, J. Brodny, E3S Web Conf., 105, 01013 (2019)

15. D. Szurgacz, L. Sobik, J. Brodny, Multidisci. Asp.of Prod. Engin., 2/1, 183-190 (2019)

16. D. Szurgacz, J. Brodny, Energies, 13/2, 405 (2020)

17. Z. Wang, T. Ren, L. Ma, J. Zhang, Energies, 11, 1564 (2018)

18. M. Tutak, J. Brodny, Appl. Sci., 9, 5315 (2019) 